\title{
The Chlorophyll Amount in the Euphotic Zone in Some Japanese Lakes and its Significance in the Photosynthetic Production of Phytoplankton Community
}

\author{
by Mitsuru SAKaMoTo*
}

Received October 25, 1965

\section{Introduction}

The photosynthetic matter production by phytoplankton community is the most important process in the metabolism of lake and marine ecosystems. From this point of view, the production of phytoplankton community in natural waters has been widely investigated by many ecologists, geochemists and oceanographers. These works have given us much information on the photosynthetic production in natural waters. However, some important problems, especially the relations between the production of community and factors controlling it, remain unsolved. The subjects concerned in the present paper, that is, the chlorophyll amount of euphotic zone and its relation to the matter production by phytoplankton community, are two of these problems.

The chlorophyll in euphotic zone is most important in the matter production in natural waters. From this point of view, some works have been done on the chlorophyll amount in euphotic zone in various kinds of waters ${ }^{1-3)}$. A little knowledge, however, has been obtained on the relation between the chlorophyll amount in natural waters and factors controlling it. As reported by many workers, the vertical distribution of chlorophyll shows various types in natural waters where underwaters light intensity decreases with depth as a result of absorption by chlorophyll itself, water and other suspending or dissolved substances. In addition, the photosynthetic activity of plankton per unit amount of chlorophyll differs with depth, waters and time. Therefore, a simple relation may not be always expected among environmental factors, chlorophyll amount of euphotic zone and the rate of photosynthetic production of phytoplankton community in natural waters.

The purpose of this paper is to examine the relation between the chlorophyll amount in euphotic zone and factors controlling it in some Japanese lakes, and moreover to clarify the significance of variation of chlorophyll amount in the photosynthetic production of community. The results of the further detailed studies on this subject will be reported in the next paper.

\section{Methods}

The photosynthetic production by phytoplankton was measured in situ with $\mathrm{O}_{2}$ method or ${ }^{14} \mathrm{C}$ technique. Transparent and black bottles of about $100 \mathrm{ml}$ capacity were filled with water taken from various depths in lake center. Without or after addition of $1 \mathrm{~m} l$ of $\mathrm{NaH}^{14} \mathrm{CO}_{3}$ solution $(2$ to $5 \mu \mathrm{c} / \mathrm{m} l$ ) these bottles were suspended for 24 hours at depths where water samples were taken. The amount of carbon assimilated

* Water Research Laboratory, Faculty of Science, Nagoya University, Nagoya, Japan. 
was estimated from the change of oxygen content in these bottles (the photosynthetic quotient was assumed to be 1) or from the uptake of ${ }^{14} \mathrm{C}^{4)}$.

The depth of euphotic zone, namely the daily compensation depth, was defined by in situ determination of the vertical distribution of daily net production. When in situ determination of production was not done, the compensation depth was estimated to be the depth where underwater light intensity was decreased to $1 \%$ of the surface intensity. The underwater light intensity was measured by a selenium rectifier photocell with a neutral filter.

For the determination of chlorophyll-a content, 0.5 to $1 l$ of the sampled water was filtrated through a $47 \mathrm{~mm}$ HA Millipore ${ }^{\circledR}$ filter within 2 or 3 hours after collection. After exposed to steam for about $30 \mathrm{sec}$, this filter was kept in a desiccator at low temperature. The chlorophyll determination was made in the laboratory after the method of Richard and Thompson ${ }^{5}$, with some modification mentioned in the previous paper6). The chlorophyll-a amount in euphotic zone per unit surface area was calculated by integrating chlorophyll-a content at every depth throughout the whole water column from surface to the bottom of euphotic zone.

\section{Results and Discussion}

1) The chlorophyll-a amount and the depth of euphotic zone in some lakes.

From 1960 to 1964, the author had frequently measured chlorophyll-a amount and the photosynthetic production of phytoplankton in some lakes of central Japan. From the results obtained, he calculated the chlorophyll-a amount of euphotic zone per unit surface area of lake. The results calculated are shown in Table 1, together with the values calculated from the data obtained by Saijo and Ichimura (unpublished). As seen evidently, the larger chlorophyll-a amount can be found in shallower eutrophic lakes. Deeper oligotophic lakes have only small chlorophyll-a amount. As far as the author's data are concerned, the maximum value was $106.0 \mathrm{mg} / \mathrm{m}^{2}$ in Lake Suwa and the minimum was $10.5 \mathrm{mg} / \mathrm{m}^{2}$ in $\mathrm{L}$. Motosu except some ice-covered lakes. Aruga and Monsi $^{2)}$ have calculated the chlorophyll amount in euphotic zone in some Japanese lakes based on Ichimura's data ${ }^{7)}$ on transparency and the mean chlorophyll content in euphotic zone. Although there are some similarities between their results and the present author's, their values are rather smaller than the author's especially in mesotrophic and oligotrophic lakes. In Ichimura's work ${ }^{7)}$, chlorophyll content was determined after the Hogetsu and Ichimura's method ${ }^{8)}$. According to my experience, the method of Hogetsu and Ichimura in chlorophyll determination, when the chlorophyll content of lake water is low, sometimes gives smaller values than the chlorophyll-a contents determined by the present method, partly because of an incomplete retaining of phytoplankton by filter paper in the former method. This may account for discrepancy between the author's values and Aruga and Monsi's.

Table 1 also shows that the chlorophyll-a amount of euphotic zone varies from month to month even in the same lake. In 1960, the annual maximum in L. Suwa was observed in April and the minimum in July, but in 1962 a large amount of chlorophyll-a comparable to the annual maximum in 1960 was obtained in July. So far as the present data are concerned, the maximum chlorophyll-a amount was observed in October 1964 in L. Kizaki and in July 1963 in L. Biwa (northern basin). The ratio of the maximum chlorophyll amount to the minimum was $5.1 \mathrm{in} \mathrm{L}$. Suwa, 4.3 in L. Kizaki and 2.2 in L. Biwa (northern basin), i.e., it was larger in eutrophic lake and 
Table 1. The chlorophyll-a amount and the depth of euphotic zone in some Japanese lakes.

* Classification according to Saijo and Hanya ${ }^{12)}$

** a - the depth defined by in situ determination. b-the depth where the light intensity decreased to $1 \%$ of that at surface.

*** Mean concentrations in euphotic zone, which were obtained by dividing the amount under unit area by De. When De was not defined in situ, b was used as a divisor.

\begin{tabular}{|c|c|c|c|c|c|c|c|}
\hline \multirow{2}{*}{ Type* } & \multirow{2}{*}{ Lakes } & \multirow{2}{*}{ Date } & \multicolumn{2}{|c|}{$\begin{array}{l}\text { Chl-a amount in } \\
\text { euphotic zone }\end{array}$} & \multicolumn{2}{|c|}{$\begin{array}{l}\text { Depth of euphotic } \\
\text { zone }(\mathrm{De})^{* *}\end{array}$} & \multirow{2}{*}{$\mathrm{Se}$} \\
\hline & & & $\left(\mathrm{mg} / \mathrm{m}^{2}\right)$ & $\left(\mathrm{mg} / \mathrm{m}^{3}\right)^{* * *}$ & $\underset{(\mathrm{m})}{\mathrm{a}}$ & $\begin{array}{c}\mathrm{b} \\
(\mathrm{m})\end{array}$ & \\
\hline 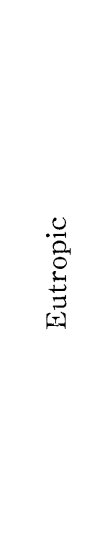 & $\begin{array}{l}\text { Kasumigaura } \\
\text { Lake Suwa }\end{array}$ & $\begin{aligned} 16 & \text { Søp. } 1956^{1)} \\
24 & \text { Nov. } 1956^{1)} \\
28 & \text { Apr. } 1958^{1)} \\
25 & \text { Feb. } 1960 \\
25 & \text { Apr. } 1960 \\
30 & \text { June } 1960 \\
19 & \text { July } 1960 \\
3 & \text { Aug. } 1960 \\
20 & \text { Oct. } 1960 \\
1 & \text { Dec. } 1960 \\
14 & \text { Apr. } 1961 \\
3 & \text { Nov. } 1961 \\
18 & \text { July } 1962 \\
20 & \text { Aug. } 1964 \\
& \\
4 & \text { Feb. } 1962 \\
9 & \text { Feb. } 1962 \\
27 & \text { Apr. } 1961 \\
19 & \text { July } 1961\end{aligned}$ & $\begin{array}{r}140.0 \\
20.6 \\
36.7 \\
39.3 \\
103.2 \\
35.8 \\
21.0 \\
55.5 \\
72.6 \\
63.4 \\
70.0 \\
59.0 \\
106.0 \\
51.4 \\
28.0 \\
67.1 \\
66.8 \\
40.0^{2)} \\
62.5\end{array}$ & $\begin{array}{r}140.0 \\
9.8 \\
18.3 \\
6.1 \\
27.9 \\
11.9 \\
5.4 \\
15.0 \\
29.0 \\
13.8 \\
16.7 \\
19.7 \\
21.2 \\
32.2 \\
20.0 \\
26.8 \\
66.8 \\
7.6 \\
12.5\end{array}$ & $\begin{array}{l}1.0 \\
2.1 \\
2.0 \\
6.5 \\
-- \\
3.0 \\
\overline{-} .7 \\
2.5 \\
4.6 \\
4.2 \\
- \\
- \\
- \\
- \\
- \\
1.0 \\
5.3^{33} \\
5.0\end{array}$ & $\begin{array}{l}- \\
- \\
\overline{7} .3 \\
3.7 \\
4.7 \\
3.9 \\
4.1 \\
2.4 \\
4.5 \\
4.0 \\
3.0 \\
5.0 \\
1.6 \\
1.4 \\
2.5 \\
- \\
- \\
-\end{array}$ & $\begin{array}{l}3.92 \\
4.08 \\
4.23 \\
3.69 \\
3.82 \\
4.11 \\
4.12 \\
3.99 \\
3.99 \\
3.87 \\
3.91 \\
4.17 \\
3.17 \\
4.17 \\
4.33 \\
4.09 \\
4.21 \\
3.87\end{array}$ \\
\hline 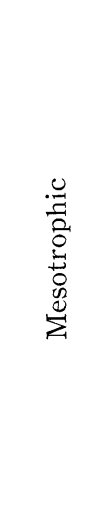 & $\begin{array}{l}\text { Lake Nakatsuna } \\
\text { Lake Haruna } \\
\text { Lake Kizaki } \\
\text { Akagiono } \\
\text { Lake Biwa } \\
\text { (Southern } \\
\text { Basin) }\end{array}$ & $\begin{array}{rll}4 & \text { Dec. } & 1958^{1)} \\
23 & \text { Aug. } 1963 \\
20 & \text { Apr. } 1958^{1)} \\
18 & \text { July } 1958^{1)} \\
17 & \text { Dec. } 1958^{1)} \\
12 & \text { Feb. } 1960^{4)} \\
9 & \text { Feb. } 1961^{4} \\
13 \text { Dec. } 1958^{1)} \\
1 \text { Nov. } 1961 \\
13 \text { June } 1962 \\
21 \text { Aug. } 1963 \\
20 \text { Aug. } 1964 \\
25 \text { Oct. } 1964 \\
10 \text { Feb. } 1960^{4)} \\
8 \text { Feb. } 1961^{4)} \\
18 \text { July } 1963 \\
14 \text { Oct. } 1963 \\
9 \text { July } 1964\end{array}$ & $\begin{array}{l}31.0 \\
74.0 \\
66.8 \\
18.5 \\
27.8 \\
10.4 \\
90.7 \\
18.6 \\
48.6 \\
27.7 \\
29.0 \\
43.8 \\
80.0 \\
10.4 \\
17.5 \\
22.6^{2} \\
24.8 \\
12.5^{2)}\end{array}$ & $\begin{array}{r}3.0 \\
6.2 \\
14.8 \\
1.5 \\
3.9 \\
1.3 \\
12.9 \\
2.5 \\
4.9 \\
4.3 \\
4.8 \\
4.4 \\
8.0 \\
1.3 \\
3.1 \\
5.7 \\
8.3 \\
3.1\end{array}$ & $\begin{array}{c}- \\
\overline{-} \\
\overline{13.0} \\
\overline{8.0} \\
\overline{-} \\
\overline{10.0} \\
6.5 \\
\overline{7.0} \\
10.0 \\
8.0 \\
\overline{4.0} \\
3.0 \\
\left.4.0^{3}\right)\end{array}$ & $\begin{array}{r}10.2 \\
12.0 \\
4.5 \\
- \\
7.2 \\
8.0 \\
7.0 \\
7.3 \\
9.0 \\
6.2 \\
6.0 \\
9.0 \\
12.0 \\
8.4 \\
5.7 \\
- \\
- \\
-\end{array}$ & $\begin{array}{l}3.69 \\
3.40 \\
3.87 \\
3.59 \\
3.84 \\
3.87 \\
3.62 \\
3.87 \\
3.65 \\
3.91 \\
3.91 \\
3.81 \\
3.43 \\
3.86 \\
3.99 \\
- \\
4.18 \\
-\end{array}$ \\
\hline 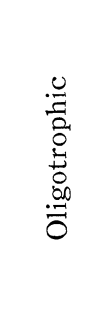 & $\begin{array}{l}\text { Lake Aoki } \\
\text { Lake Motosu }\end{array}$ & $\begin{array}{lll}25 & \text { Oct. } & 1962 \\
13 & \text { May } & 1963 \\
19 & \text { July } & 1963 \\
15 & \text { Oct. } & 1963 \\
21 & \text { Jan. } & 1964 \\
17 & \text { May } & 1964 \\
28 & \text { July } & 1964 \\
13 & \text { Dec. } & 1958^{1)} \\
24 & \text { Aug. } & 1963 \\
30 & \text { Mar. } & 1960 \\
17 & \text { July } & 1962\end{array}$ & $\begin{array}{l}40.7 \\
22.7 \\
51.0 \\
42.8 \\
34.9 \\
25.6 \\
26.3 \\
19.5 \\
20.9 \\
16.7 \\
10.5\end{array}$ & $\begin{array}{l}2.1 \\
1.0 \\
2.5 \\
2.1 \\
1.6 \\
1.1 \\
1.3 \\
0.85 \\
1.4 \\
0.33 \\
0.35\end{array}$ & $\begin{array}{l}19.0 \\
23.0 \\
20.0 \\
20.0 \\
22.0 \\
24.0 \\
20.0 \\
- \\
- \\
-\end{array}$ & $\begin{array}{l}- \\
- \\
- \\
- \\
- \\
22.0 \\
23.0 \\
15.0 \\
50.0 \\
30.0\end{array}$ & $\begin{array}{l}3.25 \\
3.23 \\
3.16 \\
3.21 \\
3.18 \\
3.15 \\
3.29 \\
3.19 \\
3.49 \\
2.39 \\
2.99\end{array}$ \\
\hline
\end{tabular}

1) Determined by Saijo and Ichimura after the method of Hogetsu and Ichimura ${ }^{8)}$ These data were not used in Figs. 2 and 3 in the present paper.

2) The amount in the whole water column from surface to lake bottom.

3) The depth of lake bottom.

4) Under the ice-covered condition. 
smaller in the oligotrophic lake. This result shows that there may be some correlation between the range of variation in the chlorophyll amount of euphotic zone and the trophic degree of lakes.

In the present work, as mentioned before, the depth of euphotic zone was directly determined from the vertical change of production rate or indirectly estimated from the relative intensity of underwater light. As seen clearly in Table 1, the depth of euphotic zone determined directly is approximately equal to that estimated indirectly. The euphotic zone is deeper in L. Motosu and L. Aoki (oligotrophic lakes) with small chlorophyll amount, and shallower in L. Kizaki and L. Haruna (mesotrophic lakes) and L. Suwa and Kasumigaura (eutrophic lakes).

The vertical attenuation of underwater light is controlled by the amount of seston and the thickness of water layer. If the effect of matter other than phytoplankton on light attenuation is not so large in euphotic zone, a definite relation may be expected between chlorophyll amount and depth of euphotic zone. As seen evidently from Fig. 1, in which the data of chlorophyll amount in Table 1 are plotted against the depth of euphotic zone of each lake, the relation between both variables is not clear. Especially, in the waters having 15 to $70 \mathrm{mg} / \mathrm{m}^{2}$ of chlorophyll-a amount, it is

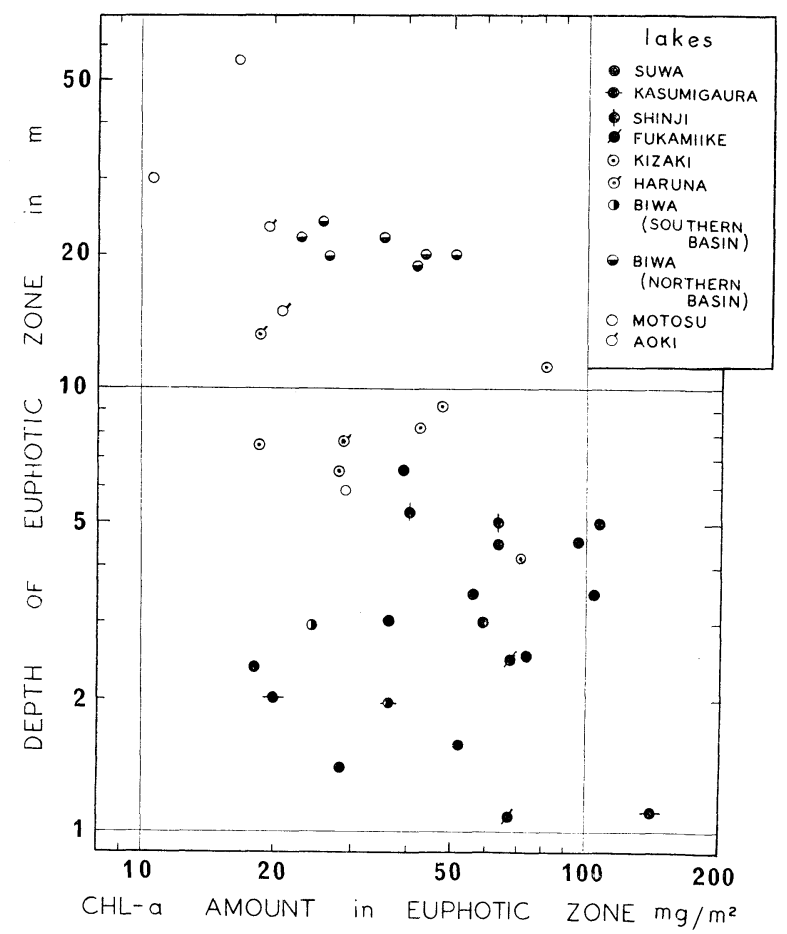

Fig. 1. Relation between the depth of euphotic zone and the chlorophyll-a amount of euphotic zone in some Japanese lakes.

impossible to find any definite relation between both variables. This suggests that the influence of substances other than phytoplankton upon the attenuation of underwater light is very large, being different with waters and with seasons.

2) Relation between chlorophyll-a amount and some factors controlling it.

The chlorophyll amount of euphotic zone is determined by chlorophyll content in 
unit volume of lake water and by the depth of euphotic zone. On the other hand, the depth of euphotic zone is affected by chlorophyll amount as well as the amount of dissolved and other suspended matter. Here, let us examine the relation between chlorophyll amount and some factors controlling it in the investigated waters. Since the light intensity at the bottom of euphotic zone is equal to $1 \%$ of surface intensity, if extinction coefficient of each substance in lake water is assumed to be constant throughout a euphotic zone, the relation between chlorophyll-a amount and the depth of euphotic zone can be expressed by the following equation:

$$
0.01=\mathrm{e}^{-(\varepsilon \mathrm{Ae}+\gamma \mathrm{De}+\mathrm{Se})},
$$

where Ae is the chlorophyll-a amount per unit area in the euphotic zone of the depth $\mathrm{De}, \varepsilon$ the light extinction coefficient of phytoplankton per unit amount of chlorophyll-a, $\gamma$ the light extinction coefficient of pure water per unit depth, and Se the product of the extiction coefficient and the amount of all dissolved and suspended substances other than phytoplankton in euphotic zone, namely the optical mass* of these substances. As 0.01 can be approximately replaced by $e^{-4.6}$, one can have from equation (1)

$$
4.6=\varepsilon \mathrm{Ae}+\gamma \mathrm{De}+\mathrm{Se},
$$

in which $\varepsilon c$ De can be substituted for $\varepsilon$ Ae if chlorophyll-a is distributed evenly at the concentration $\mathrm{c}$ in euphotic zone.

$\varepsilon \mathrm{Ae}, r \mathrm{De}$ and Se are, respectively, the terms expressing the degree of light attenuation in euphotic zone by phytoplankton, pure water and other substances. Therefore, comparing the values for these three terms in a given lake, one can examine the effect of phytoplankton, pure water and other substances on the depth of euphotic zone. Then, based on the data in Table 1, the author calculated the values for three terms in the investigated lakes. In this case, to $\varepsilon$ the value calculated on the cultured population of Synedra, 0.004, was given. The value of $\gamma$ was computed from depth of euphotic zone, the energy distribution curve of solar radiation ${ }^{9)}$ and the absorption coefficient of distilled water ${ }^{9)}$ within the range of $400 \mathrm{~m} \mu$ to $700 \mathrm{~m} \mu$. One can see from the results calculated that $\varepsilon$ Ae is from 0.04 to 0.56 and $\gamma$ De from 0.12 to 2.15 .

The column at right end of Table 1 expresses Se values calculated from the values of $\varepsilon \mathrm{Ae}$ and $\gamma \mathrm{De}$ by using equation (2). These Se values are also plotted against the depth of euphotic zone and the chlorophyll-a amount of the corresponding lakes in Fig. 2. The right ordinates in Fig. 2 express the values of $\varepsilon \mathrm{Ae}$ and $r$ De. As seen clearly, Se values are from 2.39 to 4.33 , which are much larger than the values of $\varepsilon A e$ and $\gamma$ De. This means that the substances responsible for variation of Se value have the largest influence on the attenuation of underwater light and therefore the depth of euphotic zone. Such situation can be also understood from a clear inverse relation between De and Se in Fig. 2-a. On the other hand, the present $\varepsilon$ Ae values are the smallest among the values for three terms. This means that phytoplankton has smaller influence on the depth of euphotic zone. The obscure relation found between chlorophyll-a amount and the depth of euphotic zone (Fig. 1) must have resulted from this cause. Aruga and $\mathrm{Monsi}^{2}$ reported that there was an inverse linear relation between Ae and De in the pelagic sea area near Japan. Their result seems to indicate that in this sea area Se may be very small and phytoplankton may have greater significance in the attenuation of underwater light.

\footnotetext{
* The product of extinction coefficient and mass or thickness of a given substance.
} 
For the variation of Se in the inland waters, nonliving suspended matter is most responsible. The light extinction by zooplankton and dissolved matter will be usually of less significance in harmonic lake waters. Actually, in the shallow eutrophic lakes in which much inorganic- and organic suspended matter is always supplied by inflowing rivers from the surrounding area and by wind action from lake bottom (e.g. Lake
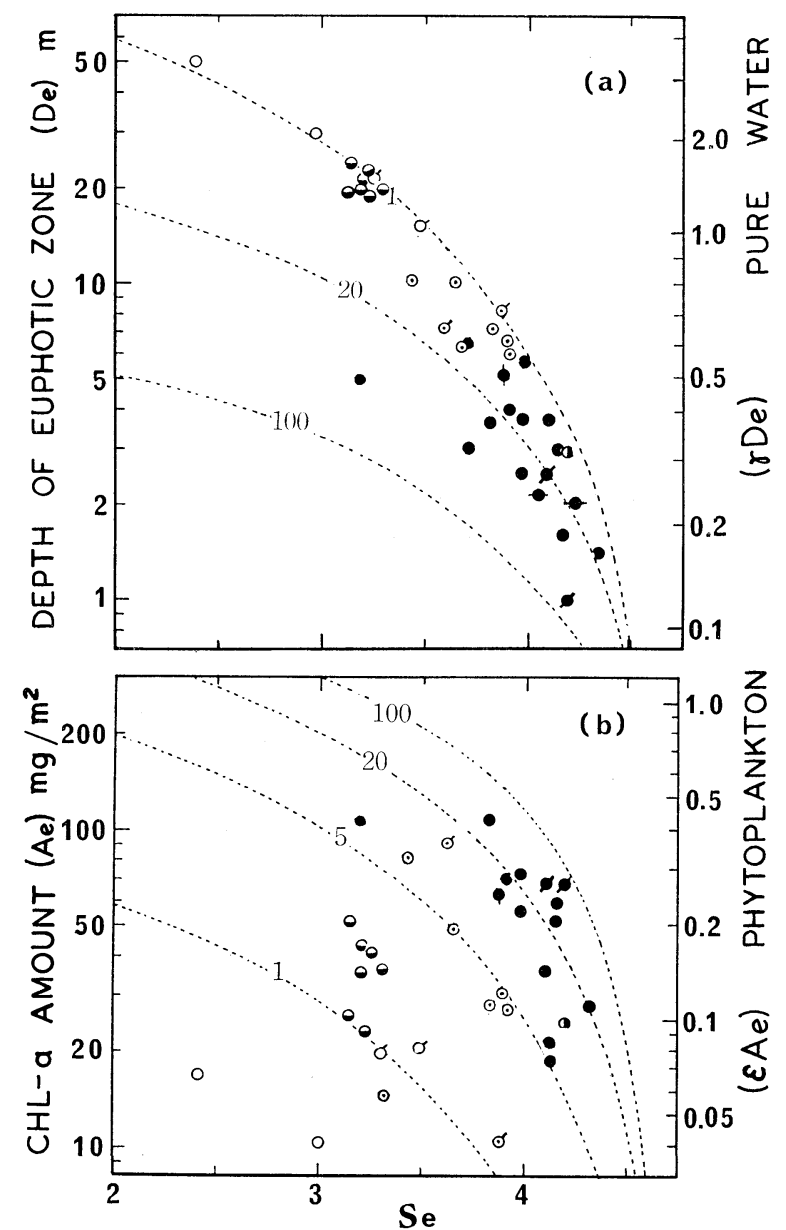

Figs. 2-a, and 2-b. Relation between the depth of euphotic zone and Seivalues (a), and that between the chlorophyll-a amount of euphotic zone and Se values (b) in some Japanes lakes. Dotted lines show the De-Se relation (a) and Ae-Se relation (b), calculated by using equation (2), in the waters where chlorophyll-a is contained in the concentration $\left(\mathrm{mg} / \mathrm{m}^{3}\right)$ shown by figures on the dotted lines. See the meanings of marks in Fig. 1. The right ordinates express the optical mass of the pure water column $(\gamma \mathrm{De}-\mathrm{a})$, and that of phytoplankton $(\varepsilon \mathrm{Ae}-\mathrm{b})$ respectively.

Suwa), Se values are large as seen in Table 1 and Fig. 2. On the other hand, in the deep oligotrophic lakes in which only a little suspended matter is supplied from the outside area, Se values are small (e.g. Lake Motosu).

Another important factor determining the chlorophyll amount of euphotic zone 
is the chlorophyll concentration of lake water. The dotted lines in Fig. 2 represent the relation between De and $\mathrm{Se}(2-\mathrm{a})$ and between $\mathrm{Ae}$ and $\mathrm{Se}(2-\mathrm{b})$ in the waters where chlorophyll-a is contained at constant concentrations in euphotic zone. These dotted lines indicate that if chlorophyll concentration of lake water is constant inverse relations can exist between De and Se, and between Ae and Se. In other words, the increase of Se must result in the decrease of De and therefore in the decrease of Ae. In the investigated waters, however, the increase of Se values was not always accompanied with the decrease of Ae, as shown by the scattering of dots in Fig. 2-b. The dotted lines with different figures in Fig. 2-b show that Ae must become larger

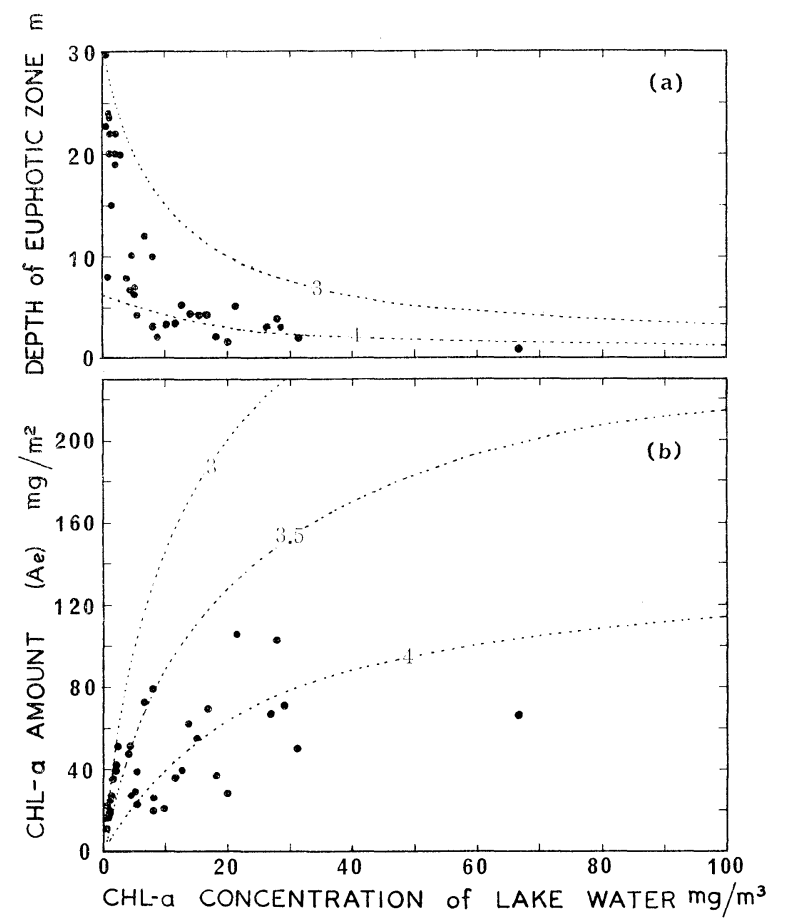

Figs. 3-a and 3-b. The relations of the mean chlorophyll-a concentration in euphotic zone to the depth of euphotic zone (a) and to the chlorophyll-a amount of euphotic zone (b) in some Japanese lakes. The dotted lines express the relation between De and chlorophyll-a concentration (a) and between Ae and chlorophyll-a concentration (b) in the ideal waters having the constant Se values shown by figures on the dotted lines.

with increase in chlorophyll concentration of lake water. The scattering of dots in this figure is, therefore, due to the difference in the chlorophyll concentration of euphotic zone in different waters and seasons. Only in L. Kizaki, an inverse relation appears to exist between Ae and Se(Fig. 2-b), owing to small variation of the data of chlorophyll concentration obtained in this work.

The dotted lines in Fig. 3-a and 3-b show the relations of chlorophyll-a concentration of lake water to De and Ae, calculated using equation (2) under the assumption that chlorophyll is distributed evenly throughout the whole euphotic zone. These lines mean that if $\mathrm{Se}$ is constant there must be a clear curvilinear relation between 
chlorophyll concentration and $\mathrm{De}(3-\mathrm{a})$ or between chlorophyll concentration and $\mathrm{Ae}(3-\mathrm{b})$. In the same figure, the mean chlorophyll-a concentration of euphotic zone in each concerned lake is plotted against $\mathrm{De}(3-\mathrm{a})$ or $\mathrm{Ae}(3-\mathrm{b})$. In spite of inconstancy of Se values, De becomes smaller with increase in chlorophyll concentration of lake water. This may be due to the fact that the waters of higher chlorophyll concentration had larger Se values (Table 1). On the other hand, a linear relation appears to exist between Ae and chlorophyll concentration in the waters of low chlorophyll concentration (Fig. 3-b, Table 1), although a definite relation can not be found in the waters of high chlorophyll concentration.

The above mentioned relation between Ae and the mean chlorophyll concentration of euphotic zone may be regarded as caused by the following situation: As seen in Table 1, the variation of Se values was large in the waters of each trophic degree, but there was no remarkable difference in the extent of their variation among the waters of three trophic degree. In the waters of high chlorophyll concentration (eutrophic lakes) where euphotic zone is shallow, therefore, the change of De brought by the variation of Se values has a larger influence on Ae than in the waters of deep euphotic zone. Thus, a definite relation could not be found between Ae and chlorophyll concentration in these lakes.. On the other hand, in the waters of low chlorophyll concentration (oligotrophic lakes), the euphotic zone is deep (Table 1). The change $(\triangle \mathrm{De})$ of De caused by variation of Se values, therefore, is not so large as compared with the depth of the euphotic zone concerned. A linear relation between $\mathrm{Ae}$ and chlorophyll concentration in the waters of low chlorophyll concentration is considered to result from such situation. It may be concluded from the above that the mean chlorophyll concentration of euphotic zone has a great significance in variation of $\mathrm{Ae}$ in oligotrophic lakes, but not in eutrophic lakes. The most important factors controlling the chlorophyll concentration of euphotic zone in harmonic lakes of Japan are the nutrient salt condition of lake water and the depth of mixing layer ${ }^{10)}$. It may be said that these factors must be also mostly responsible for the difference of Ae in oligotrophic lakes.

3) Relation between the chlorophyll-a amount of euphotic zone and the production rate of community.

The production of phytoplankton community is controlled by the chlorophyll amount of euphotic zone as well as environmental conditions and the photosynthetic activity of algae. In the studies of primary production in Lake Erken, Rodhe et al. ${ }^{11}$ ) have found a linear relation between the production rate and the chlorophyll amount of euphotic zone during the increasing phase of spring bloom, but not in other seasons. According to their explanation, these results mean that the production during the spring bloom depended mainly upon the chlorophyll amount of euphotic zone, but in other seasons it was noticeably controlled by the change of environmental conditions as well as that of the chlorophyll amount.

Fig. 4 shows the relation between the daily net production rate measured in situ and the chlorophyll-a amount of euphotic zone in the lakes investigated in the present work. As seen evidently, an approximately linear relation can be found between both variables, although there are some fluctuations of dots which seem to result mainly from the difference in environmental conditions with waters and seasons. A straight line drawn with an angle of $45^{\circ}$ to the absissa in Fig. 4 expresses the relation of production rate to the chlorophyll-a amount of euphotic zone in the waters where 


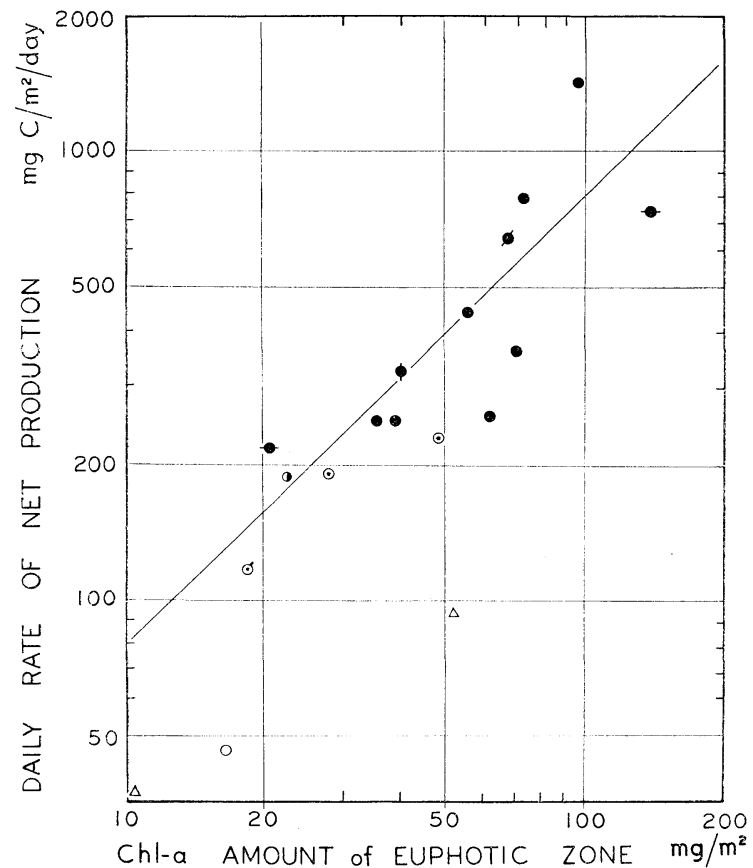

Fig. 4. Daily rate of net production per unit surface area $\left(\mathrm{mg} \mathrm{C} / \mathrm{m}^{2}\right)$ in relation to the chlorophyll-a amount of euphotic zone in some Japanese lakes. A straight line expresses the relation of Ae to the production rate of community in the waters where production rate per unit chlorophyll-a amount is $8 \mathrm{mgC} / \mathrm{mg} \mathrm{chl}$-a/day. See the meanings of marks in Fig. 1 except triangles which denote ice-covered lakes.

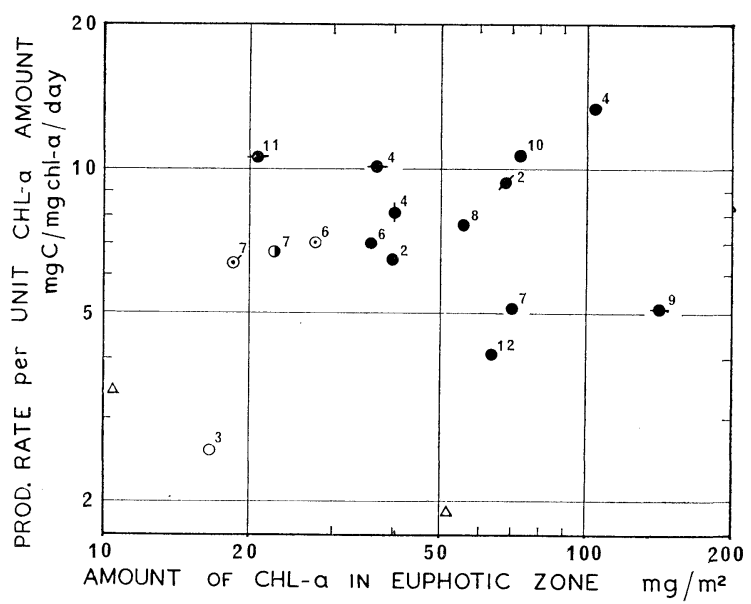

Fig. 5. Daily rate of the photosynthetic production of community per unit chlorophyll-a amount ( $\mathrm{mg} \mathrm{C} / \mathrm{mg}$ chl-a/day) in relation to the chlorophyll-a amount of euphotic zone. The figure on each plot expresses the month when the measurement was done. See the meanings of marks in Fig. 1 except triangles which denote ice-covered lakes. 
the production rate per unit chlorophyll-a amount is $8 \mathrm{mgC} / \mathrm{mg}$ chl-a/day*. In $\mathrm{L}$. Motosu having small chlorophyll-a amount, the deviation of dots from the stright line is considerable. The production rate per unit chlorophyll-a amount, i.e. the photosynthetic activity of community under the prevailing environmental conditions, is very small. This situation is more clearly presented in Fig. 5, in which the rate of production per unit chlorophyll-a amount was plotted against the chloropyll-a amount of euphotic zone. The photosynthetic rate in Lake Motosu is smaller than that in other lakes. This is mainly caused by the difference in nutrient salt conditions of lake water. Figures on dots in Fig. 5 represent the month when the production rate was measured. Although any pattern of the seasnal variation of photosynthetic rate can not be clearly recognized, the photosynthetic rate is larger in spring, summer and autumn, and smaller in winter. The extremely small values are found in some ice-covered lakes (triangles) where the penetration of incident light is remarkably prevented by the thick covered ice on lake surface.

Here, let us compare the effect of variation of chlorophyll-a amount and of photosynthetic activity upon the production of community each other. As seen clearly in Fig. 5, the ratio of the maximum chlorophyll amount to the minimum is 7 in the eutrophic lakes, and 5 in the mesotrophic lakes and oligotrophic ones. On the other hand, the ratio of the maximum photosynthetic rate of community per unit chlorophyll-a amount to the minimum is 3 in the former lakes and 3.5 in the latter. Namely, the range of variation in chlorophyll amount is two times as large as that of variation in photosynthetic activity. It may be concluded that the change of chlorophyll amount has a rather greater significance in the production of community than that of photosynthetic activity. It shall be necessary in future to examine whether or not the present conclusion is applicable to other waters with different species of plankton and under different environmental conditions.

I wish to express my thanks to Prof. Y. Saijo of Nagoya University for his encouragement and advice. My great acknowledgement is also made to Prof. K. Hogetsu of Tokyo Metropolitan University for kind reading this manuscript and making many valuable criticisms.

\section{Summary}

The variation of chlorophyll-a amount in euphotic zone was studied in some lakes of central Japan with special reference to the effect of factors controlling it, and moreover the significance of the variation of chlorophyll amount in the photosynthetic production of community was examined.

1. The large chlorophyll-a amount of euphotic zone could be found in shallower eutrophic lakes (maximum value was $106.0 \mathrm{mg} / \mathrm{m}^{2}$ in Lake Suwa), but not in deeper oligotrophic lakes (minimum was $10.5 \mathrm{mg} / \mathrm{m}^{2}$ in Lake Motosu). The depth of euphotic zone was shallower in the former and deeper in the latter. A definite relation could not be found between the depth of euphotic zone and chlorophyll-a amount of euphotic zone.

2. The optical mass of pure water ( $r$ De), of phytoplankton $(\varepsilon \mathrm{Ae})$ and of the other substances (Se) throughout the whole euphotic zone was calculated and compared each

* The mean value of the daily production rates of community per unit chlorophyll-a amount in the eutrophic waters investigated in the present work. 
other. $\varepsilon A e$ was the smallest and Se was the largest. It was concluded that the substances responsible for the variation of Se value had the largest influence on the attenuation of underwater light and therefore the depth of euphotic zone.

3. The relations of the chlorophyll amount of euphotic zone (Ae) to Se values and to the mean chlorophyll concentration of euphotic zone were examined. A clear relation could not be found between Ae and Se. Between Ae and the mean chlorophyll concentration, an approximate proportionality existed in the waters of low chlorophyll concentration, but not in those of higher chlorophyll concentration. It was concluded that the difference in chlorophyll concentration had a great significance in the variation of Ae in oligotrophic lakes.

4. The relation between the chlorophyll-a amount of euphotic zone and the daily net production rate measured in situ was examined. An approximately linear relation could be found between both variables.

5. The production rate of community per unit chlorophyll-a amount varied with waters and seasons. The range of the variation in the production rate per unit chlorophyll-a amount was generally smaller than that in the chlorophyll-a amount of euphotic zone.

\section{References}

1) Odum, H. T., Mcconnel, W., and Abbot, W., Pub. Texas Institute Marine Sci. 5: 16 (1958). 2) Aruga, Y., and Monsi, M., Plant and Cell Physiol. 4: 29 (1963). 3) Gessner, F., Hydrobotanik II. Stoffhaushalt, 631 (Veb. Deutscher Verlag der Wissenschaften, Berlin, 1959). 4) Ichimura, S., and Saijo, Y., Bot. Mag. Tokyo 71: 174 (1958). 5) Richard, F. A., and Thompson, T. G., Jour. Mar. Res. 11: 156 (1952). 6) Saijo, Y. and Sakamoto, M., Recent Researches in the Fields of Hydrosphere, Atmosphere and Nuclear Geochemistry, 289 (Maruzen, Tokyo, 1964). 7) Ichimura, S., Bot. Mag. Tokyo 69: 9 (1956). 8) Hogetsu, K., and Ichimura, S., Jap. Jour. Bot. 14: 280 (1954). 9) Clarke, G. L., Problems of Lake Biology, 27 (The Science Press, 1939). 10) Sakamoto, M., Arch. f. Hydrobiol. 62: 1 (1966). 11) Rodhe, W., Vollenweider, R. A., and Nauwerck, A., Perspectives in Marine Biology, 299 (University of California Press, California, 1960). 12) Saijo, Y., and Hanya, T., Chirigaku-Hyoron 26: 595 (1953).

\section{摘要 \\ 坂本 充: 日本のいくつかの湖に抢ける生産層中のクロロフィル $a$ 量と植物プランクトンの光 合成生産に打汀るとの意義}

中部日本のいくつかの湖で，生産颜中のクロロフィル $a$ 量とその変動を支配する装因との関係を研究し， またその変動の光合成生産にお㐨る意義を検傠した。

1) 生産壓のクロロフィル $a$ 䭪の大きな值は，一般に浅い富栄養湖で見出され，深い貧栄養湖では小さ な値しか見られない。最大值は諏訲湖における $106.0 \mathrm{mg} / \mathrm{m}^{2}$ であり，最小值は本栖湖に抢ける $10.5 \mathrm{mg}$

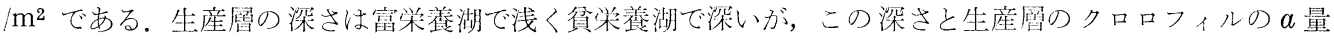
との間には明膫な量的関係はない.

2) 生産層を通じての光の消散を，植物プランクトンによるもの $(\varepsilon \mathrm{Ae})$, 純水によるもの $(\gamma \mathrm{De})$ その他 の物質…主に無機セストン…によるもの (Se)の三つの部分にわ战てそれぞれの光学的質量(optical mass) を算出した。調查された湖では， る上で Se に関係ある物質が最も主導的である。

3) 生産層中のクロロフィル濃度, および Se 㢟の生産庴のクロロフィル量 (Ae) に対する関係を検討 した。クロロフィル濃度の低い水域では Se 值が小さく, Se の変化に伴ら生産層の深さの変化は箸しくな い，てのため，Se 值に大きく左右されることなく Ae はクロロフィル濃度の変化に比例して増減する。他 方, クロロフィル濃度の高い水域では Se 值が大きく, Se の変化に伴い生産嚿の深さは著しく変るので, 
Ae とクロロフィル濃度の間の関係は, 時と場所による Se 值の差に左右されて明瞭でない.

4) 生産層中のクロロフィル $a$ 量と現場で測つた一日の生産量の間には，近似的に直線関倸がある。単 位クロロフィル $a$ 量あたりの生産量は湖や季節の差に応じて変化するが，その変化の幅は生産層中のクロ ロフィル $a$ 量の変化の幅よりも一般に小さい. (名古屋大学・理学部水質科学研究施設) 